\title{
Palaeobiogeography of the Late Carboniferous brachiopoda from Velebit Mt. (Croatia)
}

\author{
Mirko Japundžić ${ }^{1}$ and Jasenka Sremac ${ }^{2}$ \\ ${ }^{1}$ Gruška 16, 10000 Zagreb, Hrvatska; (mijapundzic@gmail.com) \\ 2 University of Zagreb, Department of Geology, Division of Geology and Paleontology, Horvatovac 102a, 10000 Zagreb, Croatia; \\ (corresponding author: jsremac@geol.pmf.hr)
}

doi: $10.4154 / g c .2016 .23$

Crossref

\section{Article history:}

Manuscript received September 30, 2015

Revised manuscript accepted June 21, 2016 Available online June 29, 2016

Keywords: Brachiopoda, palaeobiogeography, palaeoecology, Late Carboniferous, Velebit Mt. Croatia.

\begin{abstract}
An abundant and diverse Late Carboniferous brachiopod fauna from Velebit Mt. (Croatia) comprises 63 brachiopod taxa dominated by Productida and Spiriferida. The Spiriferinida, Athyridida, Orthotethida and Rhynchonellata are less common, while the Orthida, Dictyonellida and Terebratulida occur in very small numbers. Brachiopods are mostly preserved as casts and moulds in shales, limestones and sandstones. Associated fusulinid foraminifera and calcareous algae indicate a Kasimovian to Gzhelian age for the brachiopod-bearing deposits. The global biogeographic distribution of brachiopod taxa indicates the probable seaways and brachiopod migration routes, along the Euramerican shelves.
\end{abstract}

\section{INTRODUCTION}

Brachiopods are common marine macrofossils in the Late Carboniferous sedimentary rocks of Velebit Mt. They have been collected since the beginning of the $19^{\text {th }}$ century and stored in the Croatian Natural History Museum.

Upper Carboniferous (Pennsylvanian) sedimentary rocks from Velebit Mt. crop out in an elongate belt, $40 \mathrm{~km}$ long and up to $6 \mathrm{~km}$ wide, representing the core of an anticline, with a NWSE strike (Fig. 1). They exhibit a variety of ancient environments varying from shoreline forests and swamps, through coastal and shallow shelf biomes (SREMAC, 2012; CLEAL et al., 2015). Carboniferous shelves were densely populated with foraminifera (mostly fusulinids), calcareous algae, brachiopods, crinoids, bry-

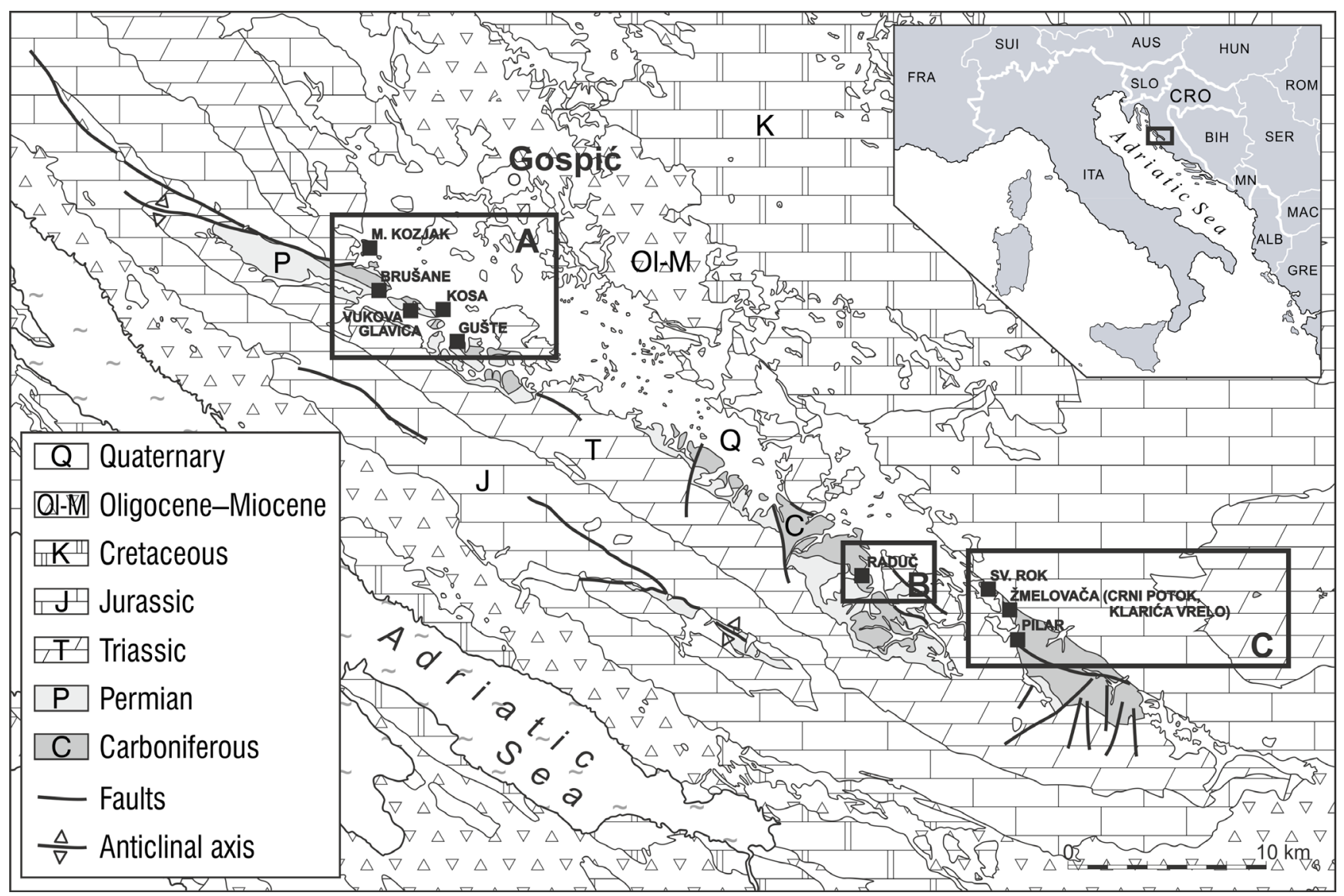

Figure 1. Simplified geological map of the research area, with the location of brachiopod observations (black squares?) (after CLEAL et al., 2015). 

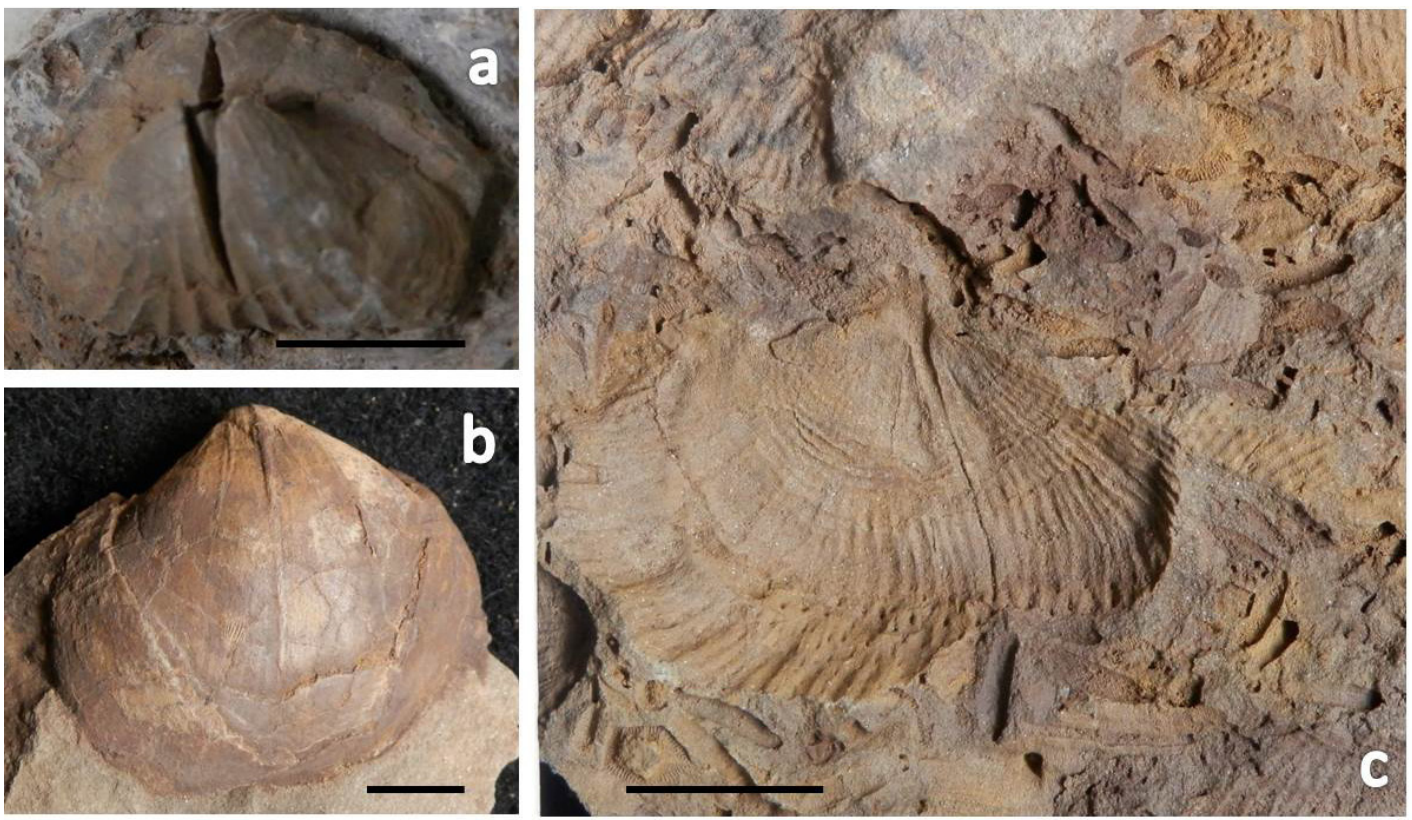

Figure 2. Modes of preservation of Late Carboniferous brachiopods in the Velebit Mt.: a) inner cast (with gaps in places of dissolved median septa) - area C; b) partly preserved shell and inner cast with visible median septum - area C; c) cast with visible external ornamentation, surrounded with fusulinid casts - area C. (Scale bar $1 \mathrm{~cm})$

ozoans and other macrofossils (SALOPEK, 1942, 1948; KOCHANSKY-DEVIDÉ, 1955, 1970; SREMAC, 2005, 2012).

A rich fossil assemblage from these deposits has been collected during mapping campaigns undertaken by M. Salopek and his students between 1935 and 1938 (SALOPEK, 1942, 1948). The geological setting of the wider area is described in Basic Geological maps of Yugoslavia on the 1:100000 scale and Basic Geological Map of Croatia 1:300 000 (IVANOVIĆ et al., 1973, 1976; SOKAČ et al., 1974, 1976a, b, c; VELIĆ et al., 2009).

Mixed siliciclastic-carbonate deposition is typical for the Late Carboniferous of this region. The stratigraphic age (late Kasimovian or earliest Gzhelian) was determined from microfossils and land megaflora (KOCHANSKY-DEVIDÉ, 1955, 1970; SREMAC, 2012; CLEAL et al., 2015).

Different lithological units in the Carboniferous of Velebit Mt. were recognized quite early by SALOPEK $(1942,1948)$. Marine macrofossils, including the brachiopods (SIMIĆ, 1935), were discovered in three lithological types: yellowish-brown shales and siltstones (cau, equivalent to the Auernig Beds according to SALOPEK, 1942, 1948), limestones (cv, according to SALOPEK, 1942, 1948) and greywackes („fusulinid sandstones“, cf, according to SALOPEK, 1942, 1948). „Fusulinid sandstones“ are more common in the lower horizons of the Late Carboniferous sequences, estimated to be of Kasimovian age, with overlying yellowish shales and siltstones of Late Kasimovian to Gzhelian age (KOCHANSKY, 1955; SREMAC, 2012). The diversity of marine fossils, including brachiopods increases from the Kasimovian to Gzhelian horizons (SREMAC, 2012).

\section{MATERIALS AND METHODS}

Carboniferous brachiopods from this study were collected by SALOPEK $(1942,1948)$ and by the present authors between 20122014. The brachiopod collection is stored in the Croatian Natural History Museum (under 96 inventory numbers).

All together 110 brachiopod specimens were determined and/or revised (SELDEN, 2007; EMIG et al., 2013; Paleobiology Database; www.fossilworks.org and references therein; August 2015) and asserted to 63 taxa.
The Carboniferous palaeogeographic map chosen to present the Carboniferous brachiopod localities is based upon Blakey's (2015) reconstruction.

\section{BRACHIOPOD TAXA}

Brachiopods were discovered in Carboniferous sedimentary rocks forming the core of the anticline on the continental slopes of Velebit Mt. (SIMIĆ, 1935; SALOPEK, 1942, 1948).

Brachiopods are in most cases preserved as casts and moulds (Fig. 2), and it is not always possible to determine them to species level.

The determined taxa belong to nine taxonomic groups: Productida, Orthothetida, Athyridida, Spiriferinida, Spiriferida, Rhynchonellida, Orthida, Dictyonellida and Terebratulida (Table 1.). Initial brachiopod taxonomy studies were based upon several published papers (e.g. VON SCHLOTHEIM, 1816; WAAGEN, 1884; SCHELLWIEN, 1892, 1900; MOORE, 1979). Taxa are revised according to the Treatise on Invertebrate Palaeontology (SELDEN, 2007). Localities with carboniferous brachiopods can be grouped into three clusters (A, B and C) with different brachiopods (Fig. 1, Tab 1., 2. Figs. 1, 3-7)

The westernmost localities (A) are dominated almost completely by productids (Linoproductus lineatus, Neochonetes granulifer, Paramesolobulus latesinuata, with small Dielasma (Tab. 1.; Fig. 3 a, 4). Altogether, 6 brachiopod specimens from this area are stored in the Natural History Museum. Moving eastwards (B), brachiopod diversity increases and, the first orthotethids and rhychonellids occur (Tabs. 1., 2.; Figs. 3 b, 5). The Eastern part of the Carboniferous belt in Velebit Mt. and the Lika region (C) comprises highly variable brachiopod assemblages, with almost a hundred specimens of productids, orthotethids, athyridids, spiriferinids, spiriferids, rhynchonellids, orthids and dictyonellids (Tabs. 1., 2.; Figs. 3 c, 6).

All the aforementioned facies types occur in all three sampling areas (SALOPEK, 1942, 1948; SREMAC, 2012), but greywackes (, Fusulinid sandstones“) are more common in the older horizons, while shales and scarce limestones prevail in the younger horizons. Brachiopod fossils are particularly numerous 
Table 1. List of Carboniferous brachiopod taxa grouped through localities in the Velebit Mt. and facies types.

(SIMIĆ, 1935; SALOPEK, 1942, 1948 and own research revised).

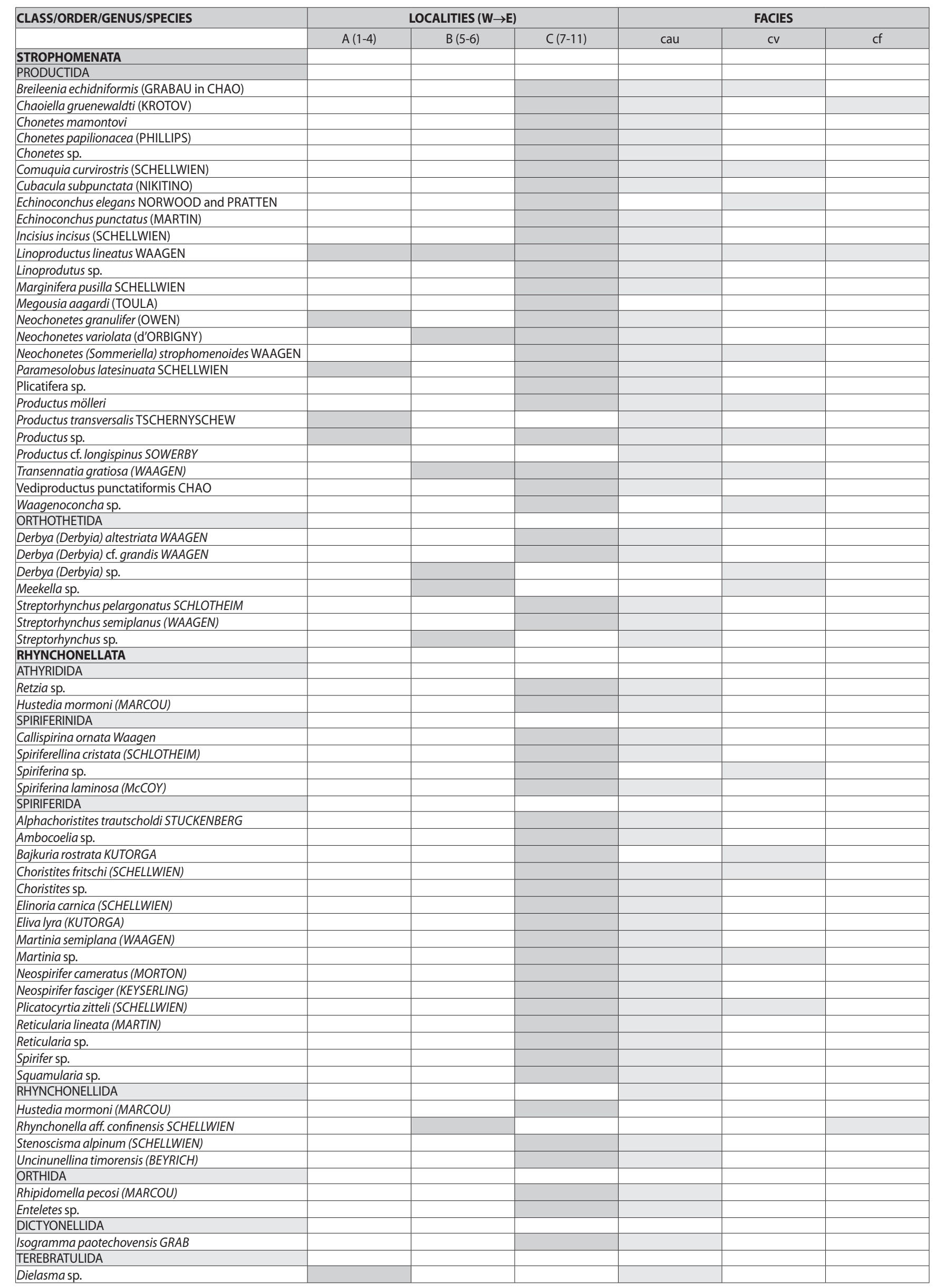



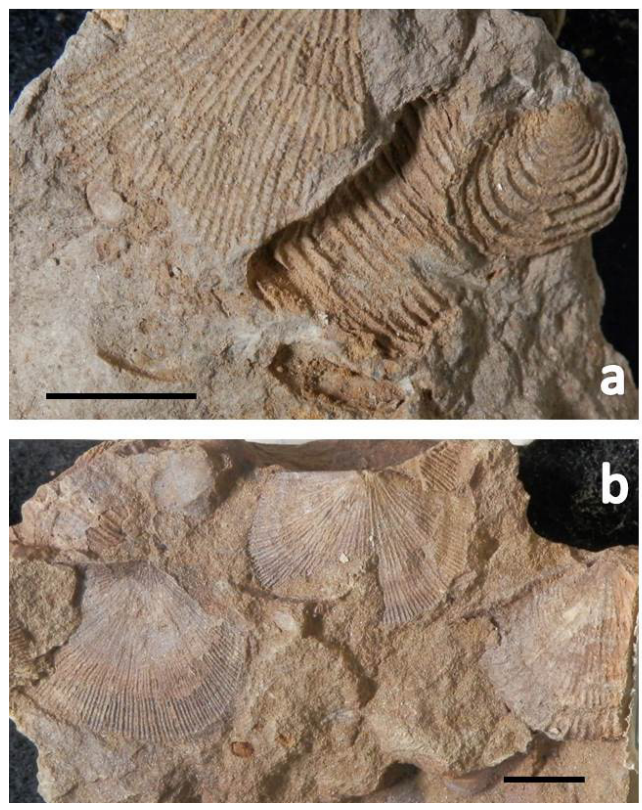

Figure 3. Differentiation of facies and brachiopod assemblages in the three examined areas with Carboniferous deposits in Velebit Mt.: a) Westernmost area (A) comprises large fenestellid casts and rather small brachiopods; b) Central area (B) is characterized by the domination of flattened orthotethids; c) Eastern localities (area C) comprise an abundant and variable brachiopod fauna, with the predomination of Productida. (Scale bar $1 \mathrm{~cm}$ )

and diverse in the shales and siltstones (cau, equivalent to the Auernig Beds according to SALOPEK, 1942, 1948). A different fossil assemblage is preserved in the limestones (cv, according to SALOPEK, 1942, 1948). Only a few brachiopod taxa were observed in the greywackes (,fusulinid sandstones“, cf, according to SALOPEK, 1942, 1948) (Tab. 1.).

\section{DISCUSSION}

\subsection{Palaeoecology and the local distribution of brachiopod genera}

Brachiopod finds are clearly grouped into three areas with different fossil assemblages (Tabs. 1., 2., Fig. 3). Palaeobiodiversity evidently increases towards the East (Tab. 2., Fig. 8). It is important to note that these three areas very rarely comprise the same taxa (Tab. 1). The exceptions are several tolerant taxa, capable of adapting to a variety of marine environments, such as Linoproductus lineatus (present in all three areas and in all lithological units - shales and siltstones, greywackes and limestones), or Transennatia gratiosa, present in the central and eastern areas, and in two of the three lithological units (shales and siltstones; limestones) (Tab. 1.).
The western area (A, Fig. 1) is characterized by several small productid taxa, with the exception of the larger Linoproductus (Tabs. 1., 2., Figs. 4 a, b). They lived anchored by spines on the soft bottom, with low depositional rates. Their low diversity and small size probably indicate restricted food sources.

The central area (B, Figs. 1, 3 b, 5 a-d), comprises some orthotethids and rhyncnonellids (Tabs. 1., 2; Figs. $5 \mathrm{~b}$, c) in addition to the productids. Linoproductus and Transennatia (Figs. 5 a, d) discovered in this area could have lived in different marine environments, from open subtidal, to basinal areas.

The presence of Neochonetes variolata (Fig. 4 a) indicates a most probable deep subtidal depositional area (KALASHNIKOV, 1993). Rhynchonella confinensis seems to be endemic, occurring only in Velebit Mt. and in the Permian deposits in neighbouring Slovenia (SCHELLWIEN, 1892).

The eastern area (C, Fig. 1) is generally rich in fossils. A well preserved terrestric megaflora indicates the vicinity of land (SREMAC, 2012; CLEAL et al., 2015). Marine fossils are diverse, with a predomination of fusulinids and crinoid ossicles, together with calcareous algae, brachiopods (Figs. 6 a-h), bryozoans (Fig. 7 a), bivalves (Fig. 7 b) and gastropods (SIMIĆ, 1935; SALOPEK, 1948; KOCHANSKY-DEVIDÉ 1955, 1970; SREMAC, 2012).
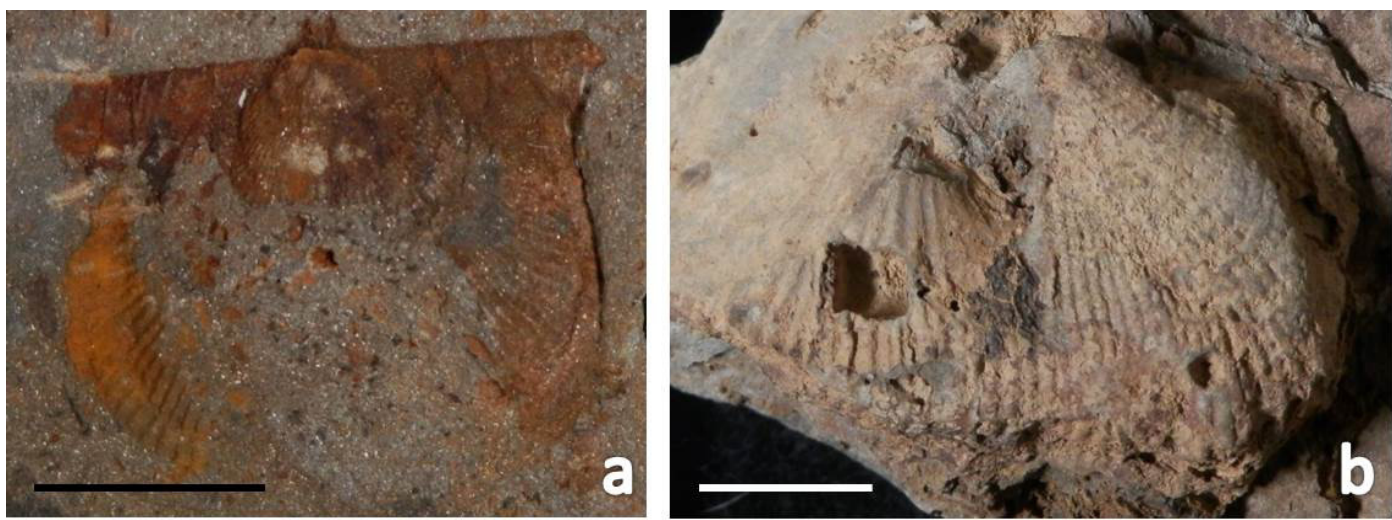

Figure 4. Mould of a Linoproductus brachial valve (a) and bioeroded cast of Productus transversalis TSCHERNYSCHEW (b) from locality cluster A. (Scale bar 1 cm) 

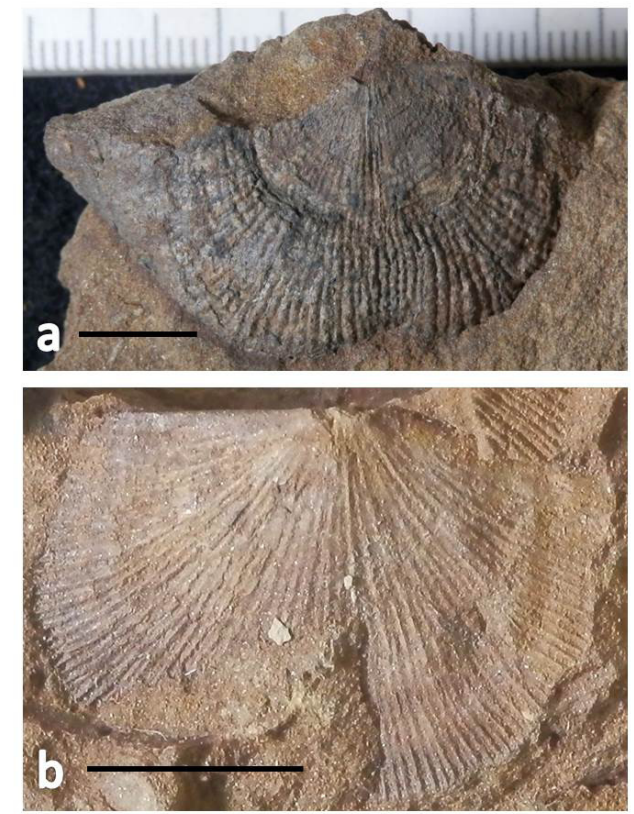
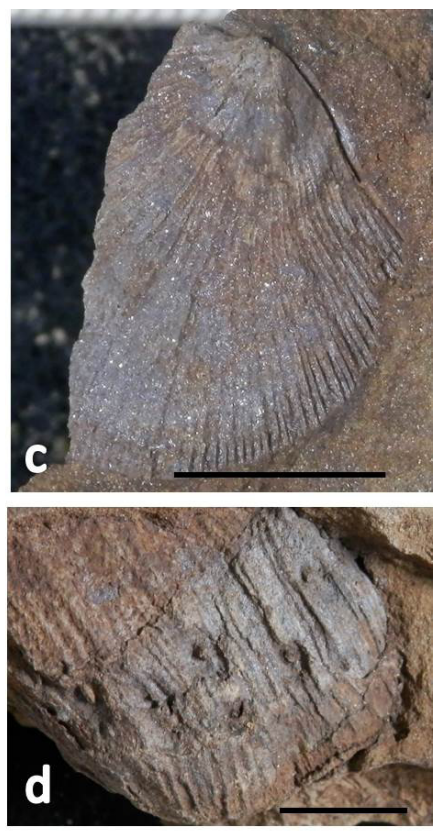

Figure 5. Transennatia (a), Derbya, (b,c) and segment of Linoproductus (d) with visible spine bases from the locality B. (Scale bar $1 \mathrm{~cm})$
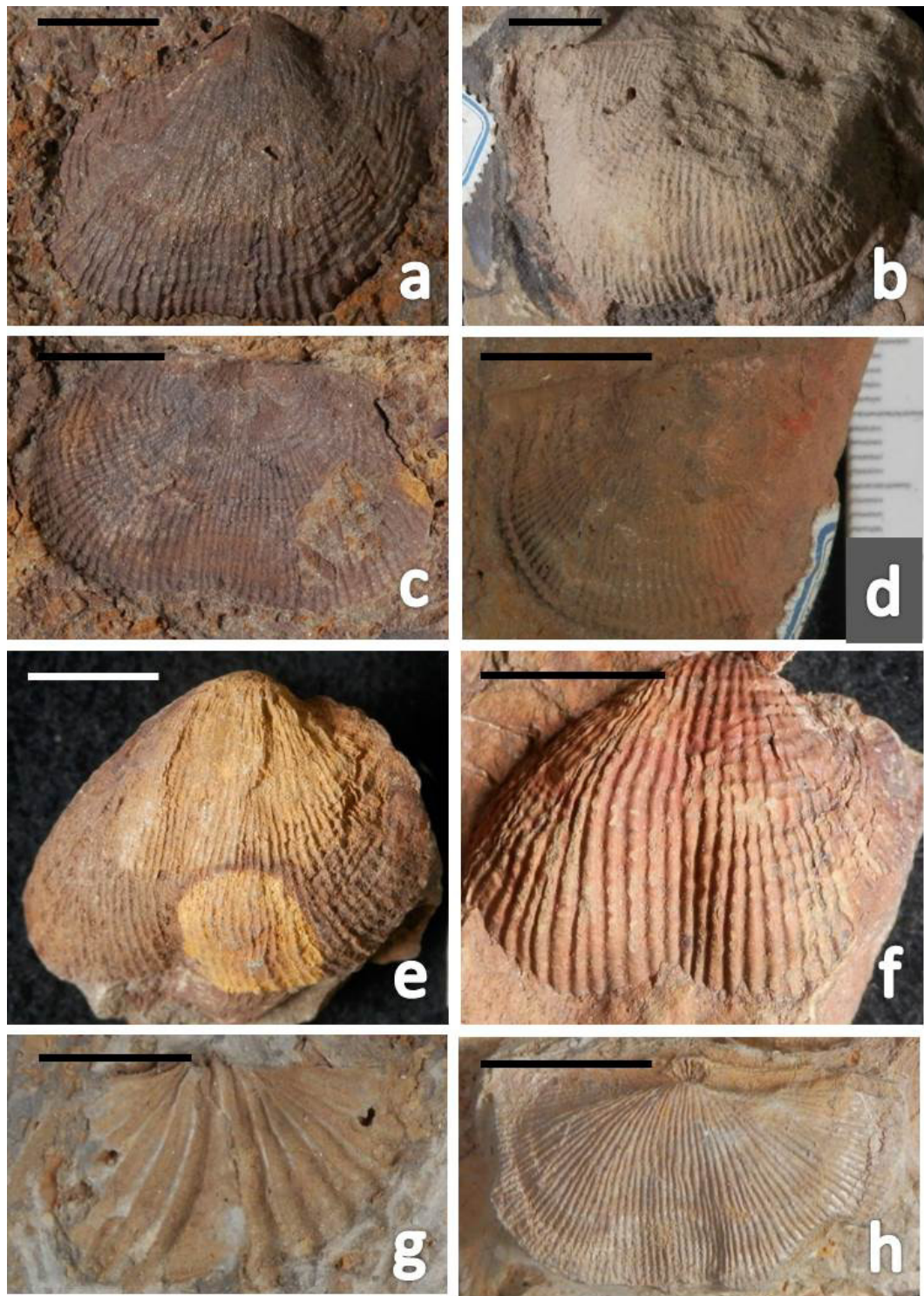

Figure 6. Productid genera (a-f): Productus (a, c, e), Dictyoclostus (b), Linoproductus (d) and Marginifera (f), spiriferinid (Spiriferina sp.) (g) and the spiriferid (Choristites) (h) brachiopoda from locality group C. (Scale bar $1 \mathrm{~cm})$ 

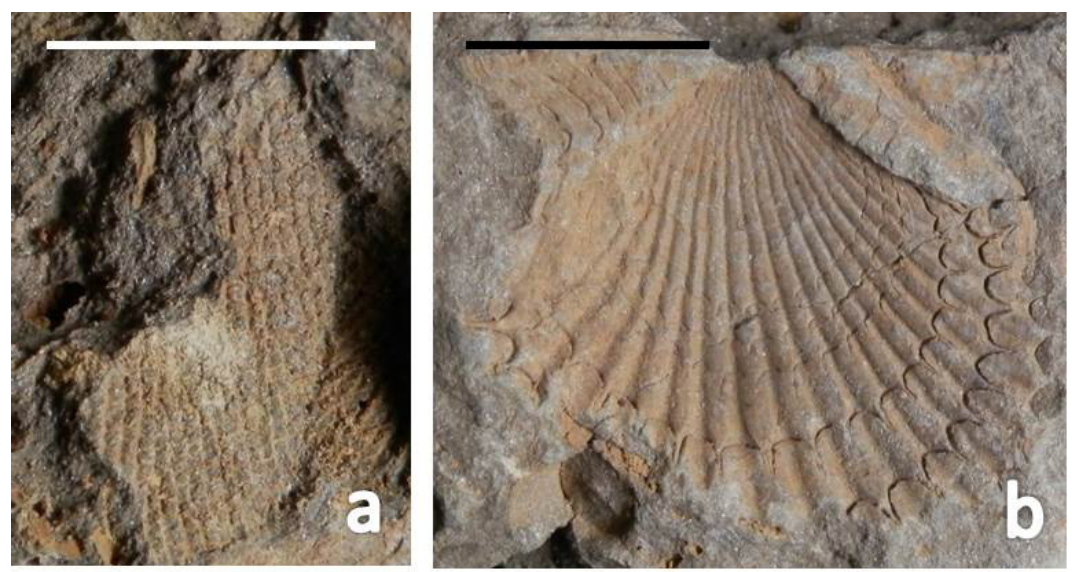

Figure 7. Cast of a fenestellid bryozoan (a) and a scallop Acantopecten sp.(b) from locality group C. (Scale bar 1cm)

Trace fossils are common in the sandstones and siltstones, present on bedding surfaces, but also within the layers, and can be attributed to the Scolithos ichnofacies.

Well sorted conglomerates and the aligned orientation of fusulinids in some sandstone layers indicate a the coastal environment. Partial or complete dissolution of fusulinid tests (SALOPEK, 1948; KOCHANSKY, 1955) indicate a probable fresh-water influence (SREMAC, 2012). Brachiopods, although numerous and highly diverse, are also mostly present as casts or moulds (Figs. 1-6). All these features indicate a variety of environments, from beaches to the more favourable subtidal niches.

Erosion of the uplifted Variscan Mountains provided nutrients and enabled the significant diversification of marine biota.
Similar trends were described from Spain (WINKLER PRINS, 2007; MERINO-TOMÉ et al., 2009).

\subsection{Palaeobiogeographic studies}

The Late Carboniferous was a time of a slight increase in brachiopod diversity (SHU-ZHONG et al., 2006) and these organisms were present in all seas and oceans. Their geographic distribution was closely related to the position of continental shelves and possible sea-ways and climate gradients, recently studied by several authors (ANGIOLINI et al., 2007; BERRA \& ANGIOLINI, 2014). During the Late Carboniferous, the study area was a part of NE Gondwana, situated near the equator (VOZAROVA et al., 2009; SREMAC, 2012; CLEAL et al., 2015)

Table 2. Total number of brachiopod taxa in three different Carboniferous areas in Velebit Mt.

\begin{tabular}{|c|c|c|c|c|c|c|c|}
\hline \multirow[b]{2}{*}{ BRACHIOPOD GROUP } & \multirow[b]{2}{*}{ TAXA } & \multicolumn{3}{|c|}{ LOCALITY GROUP A,B, C } & \multicolumn{3}{|c|}{ FACIES } \\
\hline & & $A(1-4)$ & $B(5-6)$ & $C(7-11)$ & cau & $\mathrm{cv}$ & cf \\
\hline Productida & 26 & 5 & 3 & 24 & 23 & 9 & 1 \\
\hline Orthothetida & 7 & 0 & 3 & 4 & 5 & 2 & 0 \\
\hline Athyridida & 2 & 0 & 0 & 2 & 2 & 0 & 0 \\
\hline Spiriferinida & 4 & 0 & 0 & 4 & 3 & 1 & 0 \\
\hline Spiriferida & 16 & 0 & 0 & 16 & 15 & 4 & 0 \\
\hline Orthida & 2 & 0 & 0 & 2 & 2 & 0 & 0 \\
\hline Dictyonellida & 1 & 0 & 0 & 1 & 1 & 0 & 0 \\
\hline \multirow[t]{2}{*}{ Terebratulida } & 1 & 1 & 0 & 0 & 1 & 0 & 0 \\
\hline & 63 & 6 & 7 & 56 & 54 & 16 & 2 \\
\hline
\end{tabular}

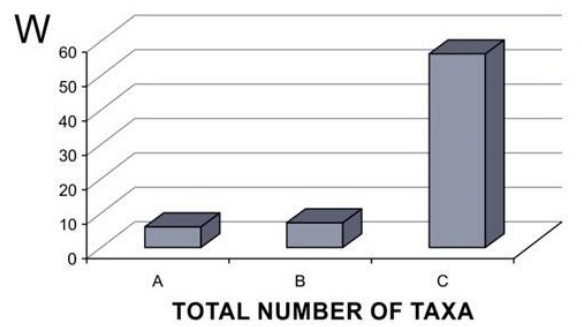

$E$
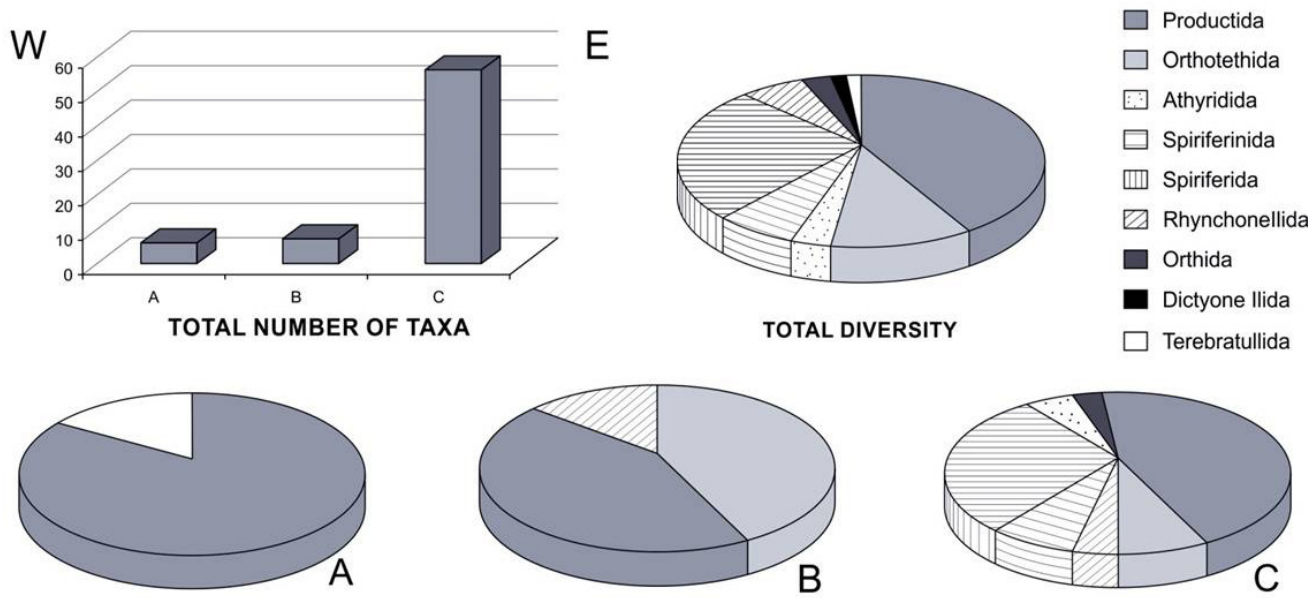

Figure 8. Total brachiopod diversity and area specific diversity for the three Carboniferous areas in Velebit Mt. 


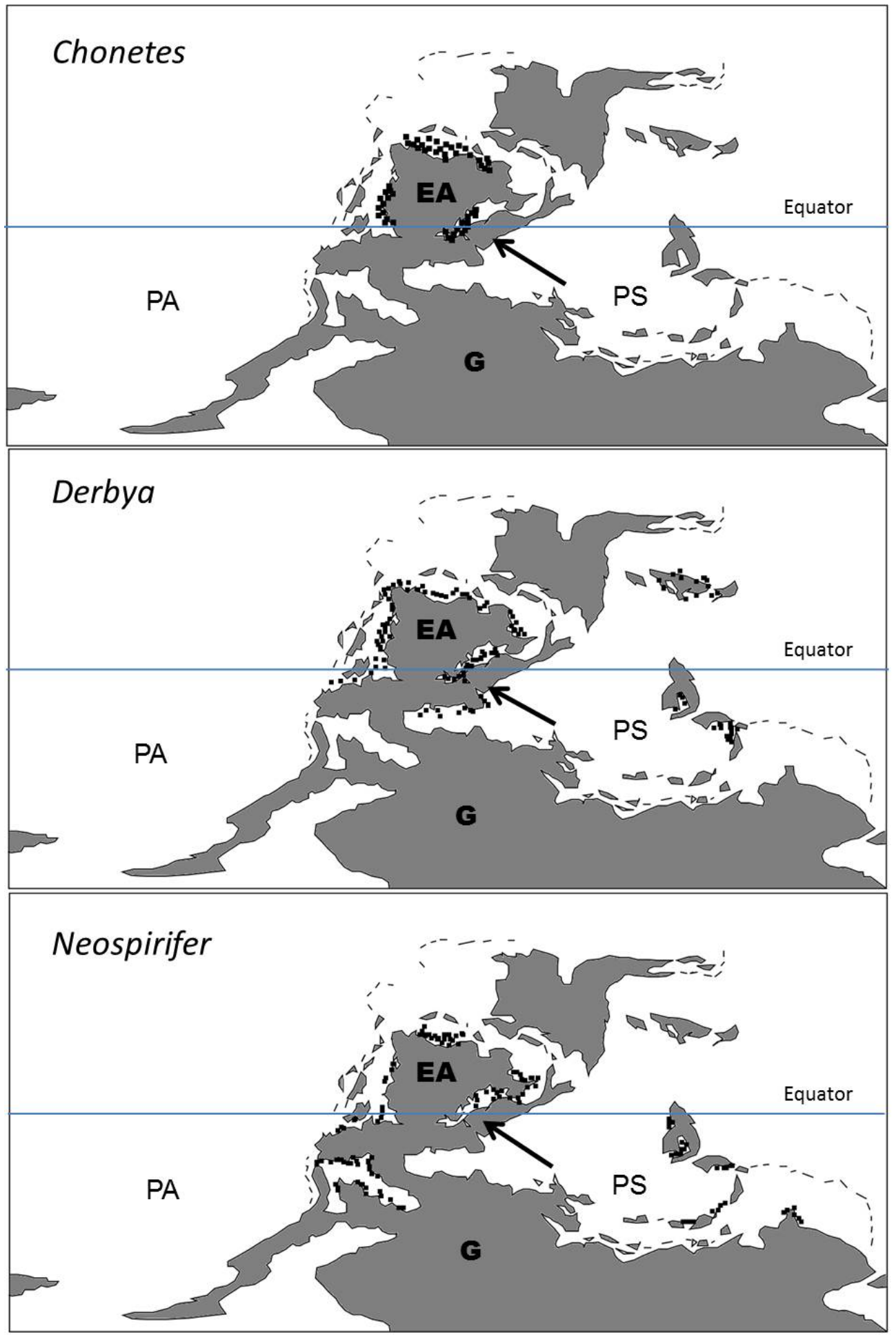

Figure 9. The Distribution of the Late Carboniferous cosmopolitan brachiopod genera (Neospirifer, Derbya, Chonetes, observed in Velebit Mt. (records from: PEDERSON, 1954; SUTHERLAND, 1991; KORA, 1995; KALASHNIKOV, 1998; SOBOLEV et al., 1998; WENDT et al., 2001; SCHNEIDER, 2003; GONG et al., 2007; http://fossilworks.org/ and references therein). Palaeobiogeography based upon Blakey's (2016) reconstruction. Grey colour: continents; white colour: oceans/seas; PS: Palaeotethys; PA: Panthalassa; G: Gondwana; EA: Euroamerica. Study area indicated by the arrow.

In order to identify possible migration routes, some of the common Carboniferous brachiopod genera from Velebit Mt. were selected for further palaeobiogeographic studies.

Tolerant brachiopod taxa (Neospirifer, Derbya) were widely spread. Disocveries of Neospirifer have been recorded in almost a thousand Carboniferous and Permian collections all over the world (PEDERSON, 1954; SUTHERLAND, 1991; KORA, 1995; KALASHNIKOV, 1998; SOBOLEV et al., 1998; WENDT et al., 2001; SCHNEIDER, 2003; GONG et al., 2007; http://fossilworks.org,
2016 and references therein). They lived all along the continental shelves of Euramerica, but also on the shelves of the southern continents and islands (Fig.9). It is possible that they had a rather longlived swimming larval stage. The genus Chonetes was also widespread, present all around Euramerica (Fig. 9). However, the geographic range of the genus Echinoconchus is very peculiar (Fig. 10) indicating possible migrations along the shelves of Panthalassa, rather than those of Palaeotethys. The genus Megousia was common on the northern shelves of Euramerica and its ap- 


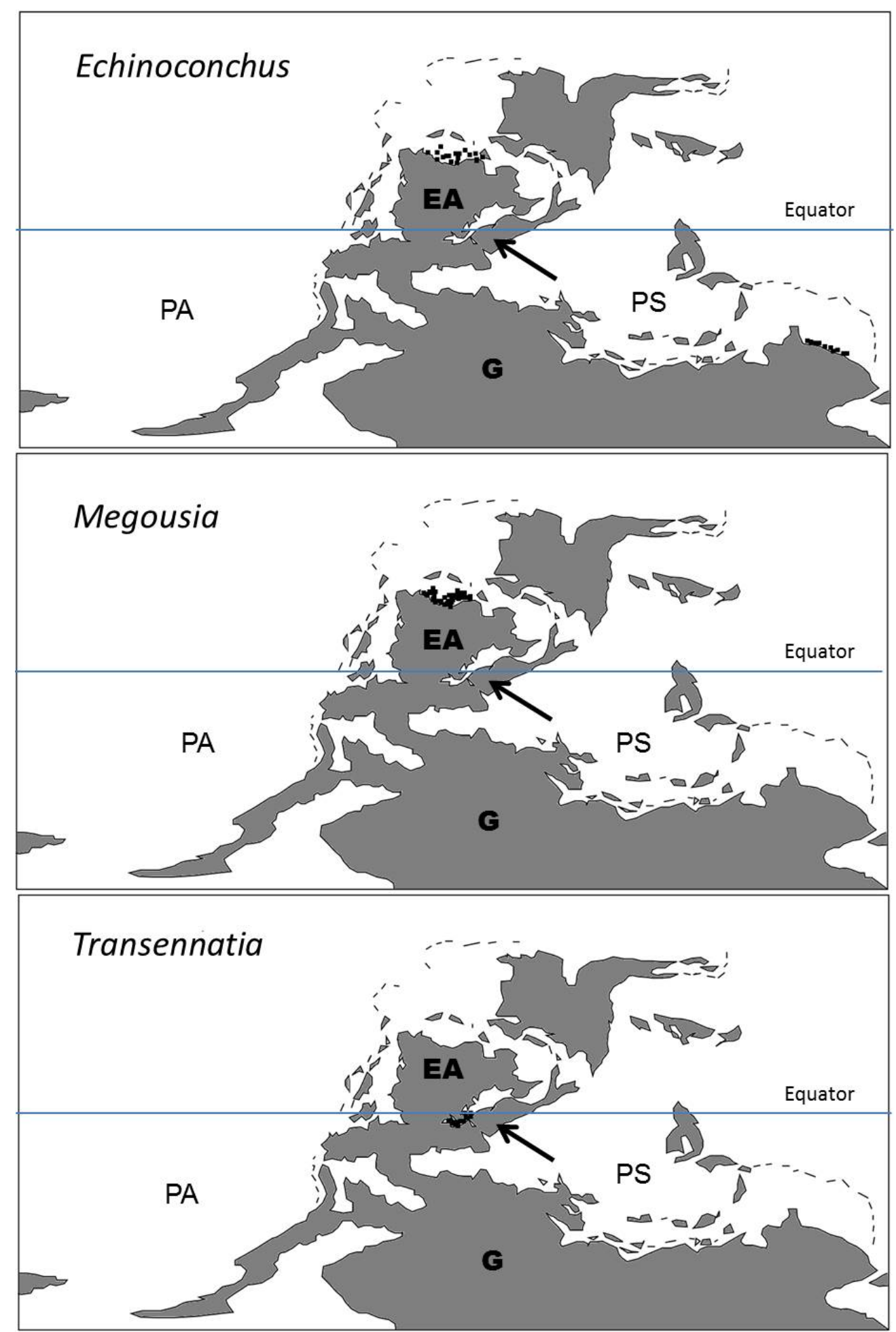

Figure 10. Distribution of the Late Carboniferous specialist brachiopod genera (Echinoconchus, Megousia, Transennatia, observed in Velebit Mt. (observations from: PEDERSON, 1954; SANDO et al., 1975; SCHNEIDER, 2003; GONG et al., 2007; HEIM et al., 2009; http://fossilworks.org/ and references therein). Palaeobiogeography based upon Ron Blakey's reconstruction (http://cpgeosystems.com/300Marect.jpg, July 2015). Grey colour: continents; white colour: oceans/seas; PS: Palaeotethys; PA: Panthalassa; G: Gondwana; EA: Euroamerica. Study area marked by arrow.

pearance near the equator is interesting (Fig. 10). Alternatively, the genus Transenatia is rather endemic, appearing on the eastern continental shelves of Euramerica, near the equator (Fig. 10).

\section{CONCLUSIONS}

The Carboniferous brachiopod fauna from Velebit Mt. is very rich and diverse. but in most cases not well preserved. All together 63 taxa were determined, belonging to nine brachiopod groups, with a predominance of productids and spiriferids.
Brachiopods were observed in the form of moulds and casts in shales and siltstones, limestones and graywackes, with the highest abundance in fine-grained clastic deposits. Three different areas with diverse brachiopod associations can be clearly recognized. The highest brachiopod diversity was observed in coastal fine-grained clastic deposits at the eastern part of the outcropping Carboniferous rock belt.

A Kasimovian to Gzhelian age was proposed on the basis of the associated fusulinid fauna. 
During the Late Carboniferous, brachiopods were common along the continental shelves of Euroamerica. Southern hemisphere records are less common and represented by tolerant genera, e.g. the cosmopolitan Neospirifer and Derbya.

\section{ACKNOWLEDGEMENT}

The authors are grateful to Sanja JAPUNDŽIĆ (Croatian Natural History Museum) for the macrophotography of the brachiopods and Robert KOŠČAL (Faculty of Science, University of Zagreb) for preparation of graphics, and to both reviewers for their contribution in the improvement of the manuscript.

\section{REFERENCES}

ANGIOLINI, 1., GAETANI, M., MUTTONI, G., STEPHENSON, M.H. \& ZANCHI, A. (2007): Tethyan oceanic currents and climate gradients 300 m.y. ago.- Geology, 35/12, 1071-1074. doi: 10.1130/G24031A.1

BERRA, F. \& ANGIOLINI, L. (2014): The Evolution of the Tethys Region throughout the Phanerozoic: A Brief Tectonic Reconstruction.-In: MARLOW, L., KENDALL, C. \& YOSE, L. (eds.): Petroleum systems of the Tethyan region. AAPG Memoir, $106,1-27$

CLEAL, C.J., TENCHOV, Y.G., SREMAC, J., ĐEREK, T. \& JAPUNDŽIĆ, S. (2015): Pennsylvanian fossil flora from the Velebit Mountains and Lika region (SW Croatia).- Bulletin of Geosciences.

EMIG, C.C.; BITNER, M.A.; \& ALVAREZ, F. (2013): Phylum Brachiopoda.-Zootaxa 3793/1, 75-78 [P. Wagner/P. Wagner]

GONG, E., SAMANKASSOU, E., GUAN, C., ZHANG, Y. \& SUN, B. (2007): Paleoecology of Pennsylvanian phylloid algal buildups in south Guizhou, China.-Facies, 53, 615-623 [W. Kiessling/U. Merkel]

HEIM, N.A. (2009): Stability of regional brachiopod diversity structure across the Mississippian/Pennsylvanian boundary.- Paleobiology, 35/3, 393.

IVANOVIĆ, A., SAKAČ, K., MARKOVIĆ, S., SOKAČ, B., ŠUŠNJAR, M., NIKLER, L. \& ŠUŠNJARA, A. (1973): Osnovna geološka karta SFRJ 1:100000, list Obrovac L33-140 [Basic Geologic Map of SFRY 1:100000, Obrovac sheet - in Croatian].- Geološki zavod, Zagreb, Savezni geološki zavod, Beograd.

IVANOVIĆ, A., SAKAČ, K., SOKAČ, B. \& VRSALOVIĆ-CAREVIĆ, I. (1976): Osnovna geološka karta SFRJ 1:100000, Tumač za list Obrovac L33-140 [Basic Geologic Map of SFRY 1:100000, Geology of Obrovac sheet - in Croatian].- Geološki zavod, Zagreb, Savezni geološki zavod, Beograd, 61 p.

KALASHNIKOV, N.V. (1993): Brakhiopody Permi Evropeiskogo Severa Rossyy [Permian brachiopods from the European northern Russia - in Russian], 151 p. Nauka, Sankt-Peterburg.

KALASHNIKOV, N.V. (1998): Permian spiriferids from the north of European Russia 1-139 [M. Clapham/M. Clapham/M. Clapham]

KOCHANSKY-DEVIDÉ, V. (1955): Karbonske i permske fuzulinidne foraminifere Velebita i Like I. Opći dio i karbon [Carboniferous and Permian fusulinids of the Velebit Mt. and Lika Region. Introduction and Carboniferous - in Croatian].- Rad Jugosl. Akad., 305, 5-62, Zagreb.

KOCHANSKY-DEVIDÉ, V. (1970): Die Kalkalgen des Karbons vom Velebit-Gebirge (Moskovien und Kassimovien).- Palaeont. Jugosl., 10, 32 p.

KORA. M. (1995): Carboniferous macrofauna from Sinai, Egypt: biostratigraphy and paleogeography.- Journal of African Earth Sciences 20/1, 37-51 [L. Ivany/P. Wall/P. Wall]

MERINO-TOMÉ, O., BAHAMONDE, J.R., SAMANKASSOU, E. \& VILLA, E. (2009): The influence of terrestrial run off on marine biotic communities: An example from a thrust-top carbonate ramp (Upper Pennsylvanian foreland basin, Picos de Europa, NW Spain).- Palaeogeogr., Palaeoclimat., Palaeoecol., 278/1-4, 1-23. doi: 10.1016/j.palaeo.2009.04.002 M

MOORE, R.C. (1979): Treatise on invertebrate Paleontology Part H, Brachiopoda. The Geological Society of America, inc. And University of Kansas Boulder. Colorado and Lawrence, Kansas. 1-554.

PEDERSON, S.L. (1954): A Permian (Wolfcampian) fauna of the Casper Formation of southeastern Wyoming.- Journal of Paleontology, 28/1, 17-21[J. Alroy/J. Alroy]

SALOPEK, M. (1942): O gornjem paleozoiku Velebita u okolici Brušana i Baških Oštarija [On the Upper Palaeozoic of the Velebit Mt. in the vicinity of Brušane and Baške Oštarije - in Croatian].- Rad JAZU., 274, 218-272.
SALOPEK, M. (1948): O gornjem paleozoiku sjeveroistočnog podnožja Velebita i Like [On the Upper Palaeozoic of the northeastern slope of the Velebit Mt. and Lika region - in Croatian].- Rad JAZU, 274, 75 p.

SANDO, W., GORDON, J.M. \& DUTRO, JR.J.T. (1975): Stratigraphy and geologic history of the Amsden Formation [Mississippian and Pennsylvanian] of Wyoming. United States Geological Survey Professional Paper 848A:1-83

SCHELLWIEN, E. (1892): Die Fauna des karnischen Fusulinenkalks, Palaeontographica, $39,1-56$.

SCHELLWIEN, E. (1900). Die Fauna der Trogkofelschichten in den Karnischen Alpen und den Karawanken I. Theil: die Brachiopoden. Abhandlungen der KaiserlichKöniglichen Geologischen Reichsanstalt, 1-122.

SELDEN, P.A. (2007): Treatise on Invertebrate Paleontology, Part H, Brachiopoda (Revised), vol. 6. Geological Society of America, Boulder, Colorado and University of Kansas Press, Lawrence, Kansas, 956 p.SHU-ZHONG, S., HUA, Z., WEN-ZHONG, L., LIN, M., JUN-FANG, Z., (2006): Brachiopod diversity patterns from Carboniferous to Triassic in South China.-Geol. J., 41, 345-361.

SIMIĆ, V. (1935): Gornjokarbonski fosili iz Like u Hrvatskoj [Late Carboniferous fossils from Lika in Croatia - in Serbian].- Vesnik Geol. Inst. Kralj. Jugosl, 1/1, 141-145.

SOBOLEV E.S., BUDNIKOV, I., V., KLETS A.G., GRINENKO, V.S. (1998): Late bashkirian ammonoids and nautiloids from western Verkhoyansk region.- Paleontological Journal 32/5, 13-25 [J. Alroy/C. Simpson/C. Simpson]

SOKAČ, B., BAHUN, S., VELIĆ, I. \& GALOVIĆ, I. (1976a): Osnovna geološka karta SFRJ 1:100000, Tumač za list Otočac L 33-115 [Basic Geologic Map of SFRY 1:100000, Geology of Otočac sheet - in Croatian].- Geološki zavod, Zagreb, Savezni geološki zavod, Beograd, $44 \mathrm{p}$.

SOKAČ, B., NIKLER, L. \& VELIĆ, I. \& MAMUŽIĆ, P. (1974): Osnovna geološka karta SFRJ 1:100000, list Gospić L 33-127 [Basic Geologic Map of SFRY 1:100000, Gospić sheet - in Croatian].- Geološki zavod, Zagreb, Savezni geološki zavod, Beograd.

SOKAČ, B., ŠČAVNIČAR, B. \& VELIĆ, I. (1976b): Osnovna geološka karta SFRJ 1:100000, Tumač za list Gospić L 33-127 [Basic Geologic Map of SFRY 1:100000, Gospić sheet - in Croatian].- Geološki zavod, Zagreb, Savezni geološki zavod, Beograd, $64 \mathrm{p}$.

SOKAČ, B., ŠUŠNJAR, M., BUKOVAC, J. \& BAHUN, S. (1976c): Osnovna geološka karta SFRJ 1:100000, Tumač za list Udbina L33- 128 [Basic Geologic Map of SFRY 1:100000, Geology of Udbina sheet - in Croatian].- Geološki zavod, Zagreb, Savezni geološki zavod, Beograd, $62 \mathrm{p}$.

SREMAC, J. (2005): Equatorial Shelf of the Palaeozoic Supercontinent - Cradle of the Adriatic Carbonate Platform.- Geol. Croat., 58/1, 1-19.

SREMAC, J. (2012): Influence of terrestrial sedimentation in Pennsylvanian rocks of Croatia.- Geol. Croat., 65/3, 274-277.

SUTHERLAND, P., K. (1991): Morrowan brachiopods from the type „Derryan“ series (Pennsylvanian), southern New Mexico.- New Mexico Bureau of Mines and Mineral Resources Bulletin, 137,186-188 [J. Alroy/C. Simpson/C. Simpson]

VELIĆ, I., ŠPARICA, M. \& VLAHOVIĆ, I. (2009): Klastične i karbonatne naslage (karbon, perm - C, P) [Clastic and carbonate deposits (Carboniferous, Permian - C, $P)$ - in Croatian].- In: VELIĆ, I. \& VLAHOVIĆ, I. (eds.): Explanatory Text for Geologic Map of Croatia 1: 300000. Hrvatski geološki institut, 20-23.

VON SCHLOTHEIM, E.F. (1816): Beiträge zur Naturgeschichte der Versteinerungen in Geognostischer Hinsicht. Denkschriften der Königlich Akademie der Wissenschaften zu Munchen für des Jahre 1816 und 1817, 6, 13-36.

VOZAROVA, A., EBNER, F., KOVACS, S., KRÄUTNER, H.-G., SZEDERKENYI, T.KRSTIĆ, B., SREMAC, J., ALJINOVIĆ, D., NOVAK, M. \& SKABERNE, D. (2009): Late Variscan (Carboniferous to Permian) environments in the Circum Pannonian Region.- Geol. Carpath., 60/1, 71-104. doi: 10.2478/v10096-009-0002-7

WAAGEN, W. (1884): Productus Limestone Fossils, Part IV, fas. 4.- Salt Range Fossils, Palaeontologia Indica, 611-728.

WENDT, J., KAUFMANN, B. \& BELKA, Z. (2001): An exhumed Palaeozoic underwater scenery: the Visean mud mounds of eastern Anti-Atlas [Morocco].- Sedimentary Geology, 145, 215-233 [W. Kiessling/U. Merkel]

WINKLER PRINS, C.F. (2007): The Role of Spain in the Development of the Reef Brachiopod Faunas During the Carboniferous.-In: RENEMA, W. (ed.): Biogeography, Time, and Place: Distributions, Barriers, and Islands, 217-246

\section{Web sources}

http://cpgeosystems.com/300Marect.jpg, last checked April 2016

http://peabody.yale.edu/sites/default/files/documents/invertebrate-paleontology/Revised $\% 20$ Treatise.pdf, last checked April 2016

www.fossilworks.org, last checked April 2016 